\title{
PRESENCE OF SPOROPHYLLS IN FLOATING KELP RAFTS OF MACROCYSTIS SPP. (PHAEOPHYCEAE) ALONG THE CHILEAN PACIFIC COAST ${ }^{1}$
}

\author{
Erasmo C. Macaya, Sebastián Boltaña, Iván A. Hinojosa, Juan E. Macchiavello, Nelson A. Valdivia, \\ Nelson R. Vásquez \\ Facultad Ciencias del Mar, Universidad Católica del Norte, Larrondo 1281, Coquimbo, Chile
}

\author{
Alejandro H. Buschmann
}

Centro de Investigación y Desarrollo en Ambientes y Recursos Costeros (i mar), Universidad de Los Lagos, Puerto Montt, Chile Julio A. Vásquez, J. M. Alonso Vega, and Martin Thiel ${ }^{2}$

Facultad Ciencias del Mar, Universidad Católica del Norte, Larrondo 1281 Coquimbo, Chile, and Centro de Estudios Avanzados en Zonas Áridas (CEAZA), Coquimbo, Chile

Some species of macroalgae continue to live for extended periods of time after detachment and may even maintain reproductive structures, yet very little is known about this process. Here, we describe the presence of sporophylls (with sporogenous tissues) on floating kelp rafts of Macrocystis spp. along the coast of Chile. Surveys were conducted at nine sites $\left(18-50^{\circ} \mathrm{S}\right)$ during austral summer 2002, and floating kelp rafts were seen and collected at seven of these nine sites (between 22 and $50^{\circ} \mathrm{S}$ ). Fifteen $(26.8 \%)$ of the 56 samples had sporophylls, indicating maintenance of sporophylls after detachment. Some of the kelp sporophytes with reproductive blades showed signs of having been afloat for long periods (indicated by the large size of attached stalked barnacles). Additionally, experiments showed that floating kelps released viable zoospores. To understand the reproductive dynamics of floating kelps, we compared these results with information from attached populations of Macrocystis spp. at nearby coastal sites. In general, attached kelp had higher proportions of sporophylls than floating rafts, suggesting that detachment may negatively affect reproductive status. Nevertheless, floating kelps remained functionally reproductive, suggesting that zoospores may be dispersed via floating rafts. Published reports on other macroalgae indicate that some species (Lessoniaceae, Fucaceae, and Sargassaceae) are fertile and probably release zoospores or zygotes while floating or drifting in ocean currents. Because dispersal distances achieved by spores of most macroalgae are relatively short, release of spores from floating algae may be an alternative mechanism of long-distance dispersal.

Key index words: Chile; detachment, dispersal; floating; kelp rafts; Macrocystis; Pacific Coast; sporophylls

\footnotetext{
${ }^{1}$ Received 19 March 2004. Accepted 17 June 2005

2Author for correspondence: e-mail thiel@ucn.cl.
}

Benthic macroalgae may become detached from primary substrata as a consequence of different biotic and abiotic factors, for example, grazing by herbivores and storms (Tegner and Dayton 1991, Dayton et al. 1992). Some of these macroalgae, for example, the sporophytes of the giant kelp Macrocystis spp., possess special gas-filled structures or pneumatocysts that allow them to float freely on the sea surface after detachment (Hobday 2000a). These algae can continue growing and maintain positive buoyancy for weeks or months after detachment (Norton and Mathieson 1983, van den Hoek 1987). For example, Hobday (2000b) estimated that detached individuals of Macrocystis pyrifera (L.) C. Agardh remained afloat for 63 to 109 days. Detached macroalgae may even reproduce and release spores (Hoffman 1987, Santelices 1990), yet very little is known about the biology of benthic algae after detachment.

Medium-range dispersal in Postelsia palmaeformis Ruprecht may be increased by transportation of fertile reproductive tissue via currents (Dayton 1973). In Sargassum muticum (Yendo) Fensholt, branches may continue producing gametes after becoming detached from the parent alga, rendering these floating fertile parts an important means of dispersal for this invasive species (Norton 1977, Critchley et al. 1983). Similarly, the appearance of Macrocystis recruits and juveniles sporophytes in previously uncolonized areas has been suggested to result from fertile floating sporophytes inoculating an area (Dayton 1985, Edgar 1987). Moreover, floating kelp rafts of Macrocystis may facilitate the reestablishment of kelp assemblages after disturbances (Vega et al. 2005).

Anderson and North (1966), who studied dispersal of Macrocystis pyrifera by examining the distribution of small sporophytes in the vicinity of adult individuals, found maximum dispersal distances of $4 \mathrm{~m}$. However, kelp dispersal may also occur over larger distances as suggested by Reed et al. (2004), who reported recruitment of Macrocystis pyrifera $3.5 \mathrm{~km}$ away from the nearest supply source. This long-distance dispersal may 
occur during storms (Reed et al. 1988), when dislodged individuals and reproductive fragments may disperse, continuously releasing spores (Gaylord et al. 2004).

In the eastern Pacific Ocean, depending on the magnitude and intensity, "El Niño" can cause localized extinctions of kelps correlated with latitude (Camus 1994, Edwards 2004), and recovery after disturbances is often explained by several mechanisms such as spore dispersal (Reed et al. 1988, Santelices 1990) or seed banks of microscopical dormant stages (Ladah et al. 1999). Floating fertile fragments might also release spores, possibly representing an alternative dispersal mechanism for some benthic macroalgae.

Floating macroalgae have been reported from many areas of the world's oceans (Kingsford 1992, Helmuth et al. 1994, Ingólfsson 1998, Hobday 2000a, Smith 2002, Thiel and Gutow 2005a), but the presence of reproductive structures usually is not mentioned. Hooker (1847), in describing the circumantarctic distribution of Macrocystis, already marveled at the floating habits of this alga: "What then is the function of the floating mass of the plant?" he queried. However, even though he observed abundant kelp floating in the southern ocean, he did not mention whether they harbored reproductive blades. Here, we describe the reproductive status of floating individuals of giant kelp
Macrocystis spp. along the coast of Chile, surveying the presence of sporophylls. We also conducted germination assays to test whether these floating algae indeed produce viable zoospores. To understand the reproductive dynamics of kelp after detachment, we compared our data on floating kelp with reproductive data from attached kelp populations at nearby coastal sites.

\section{MATERIALS AND METHODS}

Collection of floating kelp rafts and analysis of samples. During austral summer (January-March) 2002, floating kelp rafts were surveyed at nine locations (Fig. 1) on the coast of Chile along a latitudinal gradient from $18^{\circ} \mathrm{S}$ to $50^{\circ} \mathrm{S}$ (Table 1). Surveys were conducted from dawn to dusk, navigating from the coast to the west up to a distance of $\sim 50 \mathrm{~km}$ from the coast, turning south for $\sim 15 \mathrm{~km}$ before returning directly to the coast (Thiel et al. 2003). At sites where floating kelp were seen, we took samples with a special dip-net (ring diameter $60 \mathrm{~cm}$, mesh size $3 \mathrm{~mm}$ in the upper part and $0.5 \mathrm{~mm}$ in the cod end) or by a diver who carefully separated small subsamples at random from large algal patches. All sporophytes were placed in plastic bags with $5 \%$ formalin and stored for later analysis (fertile sporophylls used in germination experiments were kept without formalin, see below).

In a molecular study, Coyer et al. (2001) suggested that Macrocystis is a monospecific genus, yet along the Chilean coast two species of Macrocystis are readily distinguished based on morphological characteristics, namely $M$. integrifolia Bory de

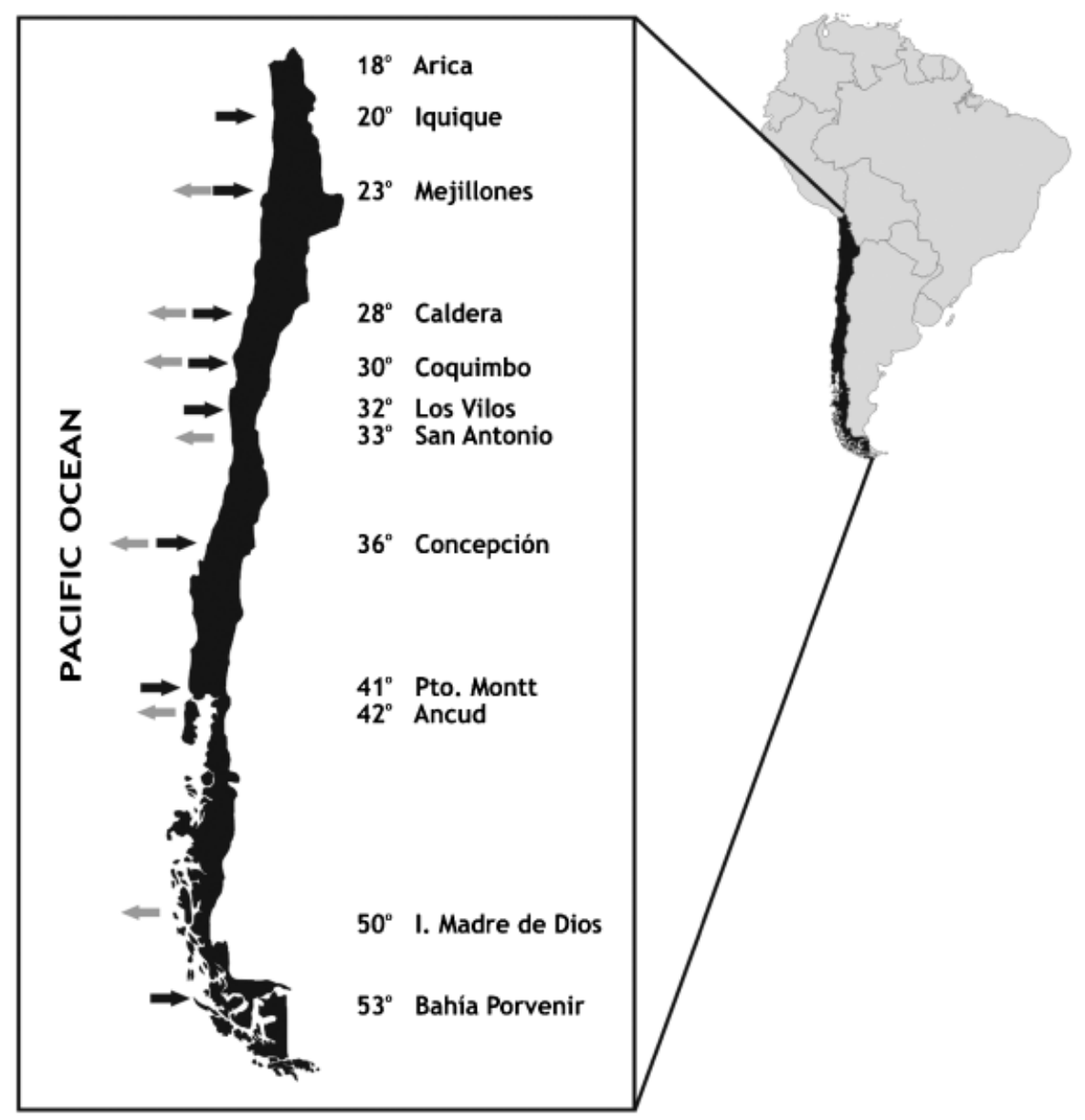

FIG. 1. Location of sampling sites of floating (gray arrows) and attached (black arrows) Macrocystis spp. from surveys conducted along the Chilean coast. 
TABlE 1. Sampling sites of floating algae, number and percent of reproductive samples, and total wet weight of samples at each sampling site (coordinates represent starting points of surveys).

\begin{tabular}{|c|c|c|c|c|c|c|}
\hline Site & Coordinates & Date & $\begin{array}{l}\text { Number of samples } \\
\text { (samples with } \\
\text { holdfast) }\end{array}$ & $\begin{array}{l}\text { Samples with } \\
\text { sporophylls (samples } \\
\text { with holdfast) }\end{array}$ & $\begin{array}{l}\text { Percent } \\
\text { reproductive } \\
\text { samples }\end{array}$ & $\begin{array}{l}\text { Total wet } \\
\text { weight } \\
(\mathrm{kg})\end{array}$ \\
\hline Arica & $18^{\circ} 27^{\prime} \mathrm{S}-70^{\circ} 20^{\prime} \mathrm{W}$ & February 2002 & 0 & - & - & _- \\
\hline Iquique & $20^{\circ} 12^{\prime} \mathrm{S}-70^{\circ} 09^{\prime} \mathrm{W}$ & February 2002 & 0 & - & - & - \\
\hline Mejillones & $23^{\circ} 04^{\prime} \mathrm{S}-70^{\circ} 30^{\prime} \mathrm{W}$ & February 2002 & $6(3)$ & 0 & 0.0 & 4.58 \\
\hline Caldera & $27^{\circ} 04^{\prime} \mathrm{S}-70^{\circ} 64^{\prime} \mathrm{W}$ & February 2002 & $7(3)$ & 0 & 0.0 & 1.91 \\
\hline Coquimbo & $29^{\circ} 57^{\prime} \mathrm{S}-71^{\circ} 22^{\prime} \mathrm{W}$ & February 2002 & $10(3)$ & $4(3)$ & 40.0 & 4.86 \\
\hline San Antonio & $33^{\circ} 35^{\prime} \mathrm{S}-71^{\circ} 42^{\prime} \mathrm{W}$ & March 2002 & $6(4)$ & $2(1)$ & 33.3 & 5.31 \\
\hline Concepción & $36^{\circ} 44^{\prime} \mathrm{S}-73^{\circ} 13^{\prime} \mathrm{W}$ & March 2002 & $11(5)$ & $6(5)$ & 54.5 & 11.86 \\
\hline Ancud & $41^{\circ} 46^{\prime} \mathrm{S}-73^{\circ} 58^{\prime} \mathrm{W}$ & March 2002 & 7 (3) & $3(2)$ & 42.9 & 6.21 \\
\hline I. Madre de Dios & $50^{\circ} 26^{\prime} \mathrm{S}-75^{\circ} 22^{\prime} \mathrm{W}$ & March 2002 & $9(1)$ & 0 & 0.0 & 3.74 \\
\hline Total & & & $56(22)$ & $15(11)$ & 26.8 & 38.47 \\
\hline
\end{tabular}

Saint-Vincent, with a flat holdfasts and narrow blades, and $M$. pyrifera with a high holdfast and wide blades. Sporophytes collected in the present study were morphologically representative of both species (holdfast and blade observations), but because the taxonomic situation of the genus Macrocystis has not yet been satisfactorily resolved, we herein treat all samples as Macrocystis spp. With the exception of the northern-most site where we collected floating kelps (Mejillones), samples were monospecific at all sampling sites, with samples from Caldera and Coquimbo corresponding morphologically to $M$. integrifolia and those from San Antonio and south to M. pyrifera.

In the laboratory, blades or individual sporophytes were carefully washed with fresh water. For each sample we counted the total number of vegetative blades and sporophylls (Reed 1987, North 1994). The presence of sporangia was confirmed by transverse sections of the blades and microscopical examination. For each sample the total wet weight $(0.1 \mathrm{~g})$ of vegetative blades and sporophylls was taken separately. Additionally, when samples contained stalked barnacles these were removed and counted, and the length of the scutum was measured for the 20 largest individuals from each sample. Stalked barnacles (Lepas spp.) were used, because 1) these animals are common on floating substrata but are not found on attached kelp individuals (Chen and Lewin 1976, Bernstein and Jung 1979, Helmuth et al. 1994), and 2) the body sizes of these barnacles serve as good proxies of minimum floating time (Thiel and Gutow 2005b).

Sampling of kelp from benthic populations and analysis of samples. The number of sporophylls and abundance of kelp sporophytes in benthic populations was evaluated using data collected during the summer periods of 2000-2004 (i.e. when oceanographic conditions were similar as in the summer 2002). Information on attached kelps was obtained from Iquique (January 2000), Mejillones (March 2003), Caldera (January 2002), Coquimbo (February 2002), Los Vilos (January 2004), Concepción (January 2002), and Pto. Montt (February 2002) (Fig. 1). Data on the proportion of sporophylls from benthic populations at the southern-most site, Bahía Porvenir $\left(53^{\circ} \mathrm{S}\right)$, were obtained from the literature (Mansilla et al. 2003).

The abundance of Macrocystis spp. was estimated using several replicate counts of $1-\mathrm{m}^{2}$ quadrates along a transect perpendicular to the coast between the shoreline and $15 \mathrm{~m}$ depth covering the entire depth range of kelp beds. Sporophyte abundance was expressed as the number of sporophytes per square meter. Adult sporophytes were sampled at each site, and the total numbers of vegetative blades and sporophylls per individual were counted.

Viability of zoospores from floating kelps. During austral summer and fall (January and May 2004, January and April
2005), floating kelp rafts of Macrocystis spp. were collected in offshore waters off the Coquimbo coast (Fig. 1). Sporophylls were separated from these algae and transported to the laboratory in a cooler. Zoospores were obtained using the method of Reed et al. (1991). To evaluate the viability of zoospores (measured as number of zoospores with germination tubes versus total number of zoospores), three replicate Petri dishes $(5 \mathrm{~cm}$, diameter and grid bottom) filled with $10 \mathrm{~mL}$ filtered seawater were inoculated with $2 \mathrm{~mL}$ spore solution and maintained for 3 days under the following conditions: $15 \pm 1^{\circ} \mathrm{C}$, $30 \pm 5 \mu \mathrm{mol}$ photons $\cdot \mathrm{m}^{-2} \cdot \mathrm{s}^{-1}, 16: 8$-h light:dark cycle. Following this incubation period, zoospore viability was measured from the entire field of the microscope $(n=10$ counts per Petri dish). The measurements were conducted with an inverted microscope $(400 \times)$.

\section{RESULTS}

At the two northern-most sampling sites (Arica and Iquique), no floating kelp rafts were seen, but abundant floating kelp rafts were recorded at the other sampling sites. At each of those latter sites, between 6 and 11 samples were taken (Table 1). The size of the kelp rafts varied from small pieces (only stipes with some blades) to large patches of algae (several individuals including holdfasts) of more than $100 \mathrm{~kg}$ wet weight. The wet weight of individual samples varied from 0.034 to $5.64 \mathrm{~kg}$ in Coquimbo and Concepción, respectively (Table 1). Most samples with sporophylls also contained holdfasts (Table 1). Floating kelp rafts with sporophylls were only found at the four sampling sites between $30^{\circ} \mathrm{S}$ and $41^{\circ} \mathrm{S}$. No sporophylls were found in floating algae from the northern sites (Mejillones and Caldera) or southern-most site (Isla Madre de Dios). The highest abundance of sporophylls was found in San Antonio ( $\left.33^{\circ} \mathrm{S}\right)$, with one sample containing almost $70 \%$ reproductive blades (Fig. 2a). Similarly high values were observed for some samples in Concepción ( $\left.36^{\circ} \mathrm{S}\right)$. In general, sporophylls were in good conditions, with the sporangial tissue covering a large area of the blade. The sporophylls often comprised a large proportion of the entire blade biomass in a sample, and the highest biomass of sporophylls was found in Concepción where in one sample almost $80 \%$ of the total blade biomass consisted of sporophylls (Fig. 2b). 


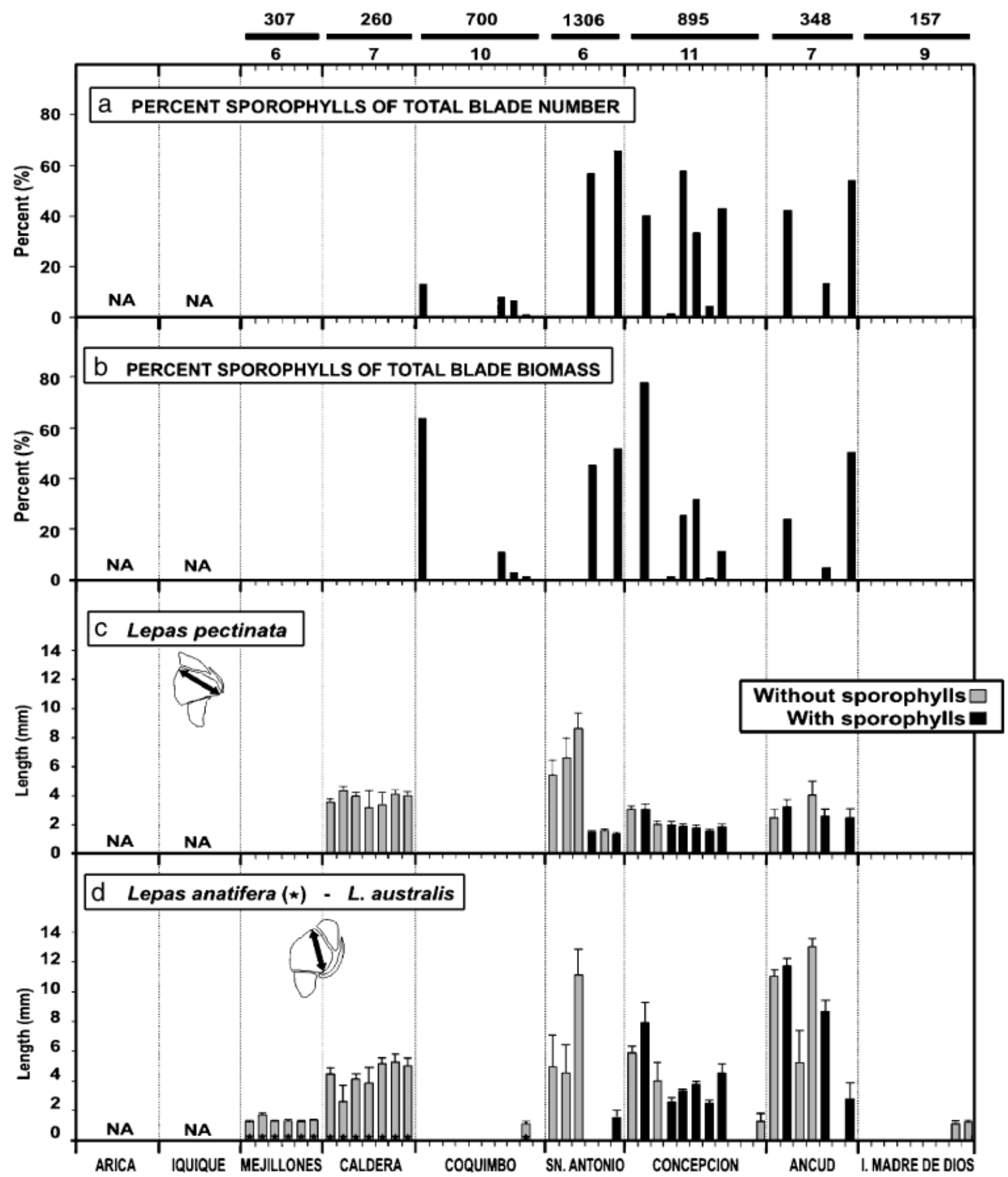

FIG. 2. Proportion of sporophylls in individual samples from each site and size of stalked barnacles associated with these samples. (a) Number of sporophylls as a percentage of the total number of blades (vegetative and sporophylls) for each sample at each site; numbers on top of horizontal bars represent the total number of blades and number below bars represent number of samples collected at each site. (b) Sporophyll biomass as a percentage of the total wet weight of blades for each sample. (c) Mean scutum length $(+1 \mathrm{SD})$ of the 20 largest individuals of Lepas pectinata in samples with and without sporophylls. (d) Mean scutum length (+ 1SD) of the 20 largest individuals of Lepas australis and Lepas anatifera (gray bars with star) in samples with and without sporophylls. NA, no algae were found at these sites.

Four species of stalked barnacles were found on the floating algae, namely Lepas anatifera Linnaeus, L. pectinata Spengler, L. australis Darwin, and Dosima fascicularis Ellis \& Solander (the latter species only occurred with few individuals in two samples from Caldera and one from San Antonio). Lepas anatifera occurred exclusively in samples without sporophylls principally on kelp rafts from the northern sites 


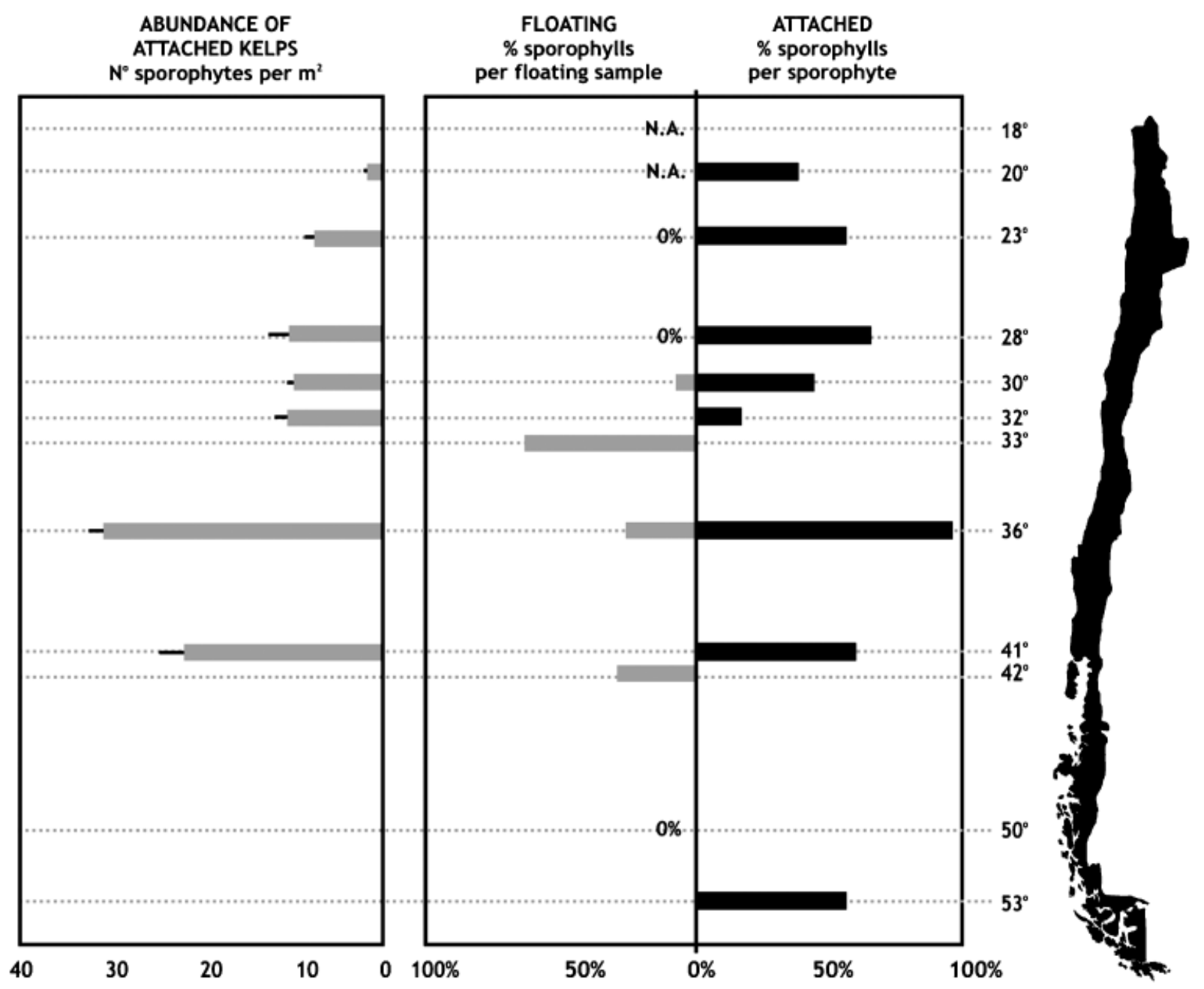

FIG. 3. Comparison of data from floating versus attached algae and abundance of algae along the Chilean Coast. Percent of sporophylls of total samples from each site in floating algae and percent of sporophylls per sporophyte in attached algae. Black lines in abundance data represent SE. NA, no algae were found at these sites.

(Fig. 2d), and the maximum sizes of these individuals was $5.5 \pm 0.5 \mathrm{~mm}$ scutum length. Only two species occurred in samples with sporophylls: L. pectinata and L. australis (Fig. 2, c and d). Large individuals were found in the samples from three sites (San Antonio, Concepción, and Ancud), with maximum sizes in Concepción and Ancud for L. australis $(8.1 \pm 1.4 \mathrm{~mm}$ and $12.4 \pm 0.5 \mathrm{~mm}$ scutum length, respectively). The sizes of these stalked barnacles, which only colonize floating items, suggested that kelp had been floating for relatively long time periods. Interestingly, kelp rafts from San Antonio with high proportions of sporophylls contained no or only very small barnacles (Fig. 2). Similarly, in Ancud the sample with the highest proportion of sporophylls only contained relatively small barnacles (Fig. 2).

The abundance of attached Macrocystis spp. along the Chilean coast showed low values in Iquique (2.0 sporophytes $\cdot \mathrm{m}^{-2}$ ). Between $23^{\circ} \mathrm{S}$ and $33^{\circ} \mathrm{S}$, kelp abundance reached values of $8.0-11.0$ sporophytes $\cdot \mathrm{m}^{-2}$, and the highest values (37 sporophytes $\cdot \mathrm{m}^{-2}$ ) were reached in Concepción (Fig. 3). In general, the percentage of sporophylls on attached sporophytes was higher than on floating kelps (Fig. 3). The highest values with $96.5 \%$ were reached in Concepción, where the mean number of sporophylls per sporophyte was 3.2 with only four blades (vegetative plus reproductive) in total (adult individuals had lost most of their vegetative biomass due to storm-induced loss of stipes). Only in San Antonio was the percentage of sporophylls on floating kelp higher than on attached kelps $(64 \%$ versus $18 \%$, respectively). In general, the percent of sporophylls on attached kelps of Macrocystis was at least $50 \%$, and we never found algae without reproductive blades. In contrast, the floating algae from several sites had no sporophylls.

All examined sporophylls from floating kelp rafts collected in offshore waters off the coast of Coquimbo $\left(30^{\circ} \mathrm{S}\right)$ released zoospores (Table 2$)$. At the first three sampling dates, more than $60 \%$ of all zoospores germinated, whereas in April 2005 germination rates where slightly below $50 \%$. The mean diameter of 
TABLE 2. Germination (\%) of floating samples of Macrocystis collected in offshore waters off the Coquimbo coast.

\begin{tabular}{lcc}
\hline \hline Date & $\begin{array}{c}\text { Percent } \\
\text { germinated }\end{array}$ & $\begin{array}{c}\text { Total of zoospores } \\
\text { counted }\end{array}$ \\
\hline January 2004 & $80.8 \%$ & 6814 \\
May 2004 & $66.4 \%$ & 4445 \\
January 2005 & $78.1 \%$ & 4487 \\
April 2005 & $46.1 \%$ & 4265 \\
\hline
\end{tabular}

zoospores was $11.4 \mu \mathrm{m}( \pm 6.7 \mu \mathrm{m} \mathrm{SD})$, and these were mobile and capable of settlement.

\section{DISCUSSION}

Our results suggest that kelp sporophytes maintained sporophylls while floating. Some of the floating kelps that we collected were very reproductive, as judged by the high number of sporophylls, even though they had been afloat for at least 2 weeks, as indicated by the fact that they were colonized by large individuals of stalked barnacles. These observations have important implications for the dispersal and recruitment capabilities of kelp species. Below we discuss the dispersal potential of Macrocystis spp. and provide literature examples to show that continuing reproductive activity may be common in detached macroalgae. Finally, we discuss the importance of this process as an alternative dispersal mechanism for some marine macroalgae.

Reproductive activity of floating and attached Macrocystis $s p p$. No kelps were found floating at the northern-most study sites (Arica and Iquique), even though Macrocystis beds extend along the entire Chilean and southern Peruvian coast (Vásquez and Buschmann 1997). One possible reason for the absence of floating algae could be the low density of individuals in kelp forests from the northern-most sites. The interannual changes in abundance of kelp species at low latitudes $\left(23^{\circ} \mathrm{S}\right.$ to $\left.20^{\circ} \mathrm{S}\right)$ in the southeast Pacific is regulated by "El Niño" (Camus 1994, Edwards 2004) with extreme cycles of distribution and kelp abundance that can last years or decades (Martinez et al. 2003, Vega et al. 2005). During 2002, Macrocystis populations in northern Chile were still recovering from the 1997-1998 El Niño disturbance (Vega et al. 2005). Recolonization processes after El Niño along the South American coast are slow (Martinez et al. 2003) and could explain the low sporophyte abundance at the northern sites compared with southern sites. However, even though density of Macrocystis spp. was low at the northern sites, the geographic extension of kelp beds between $23^{\circ} \mathrm{S}$ and $20^{\circ} \mathrm{S}$ was high in 2002 (unpublished results). Thus, lack of supply from benthic populations cannot alone be responsible for the total absence of floating kelp in Arica $\left(18^{\circ} \mathrm{S}\right)$ and Iquique $\left(20^{\circ} \mathrm{S}\right)$. Floating kelp rafts at the northern sites may disintegrate rapidly after detachment due to unfavorable conditions.
During the study period in summer 2002, surface water temperatures in offshore waters of Arica and Iquique were $>20^{\circ} \mathrm{C}$ (unpublished data). Temperatures exceeding $20^{\circ} \mathrm{C}$ for several weeks are probably harmful to Macrocystis stands in nature (North 1994, Vega et al. 2005). In experiments with gametophytes, Peters and Breeman (1993) also found that these high temperatures are close to the survival limits of this kelp. Deysher and Dean (1986) suggested that a lack of sporophyte production may be caused by a combination of high temperatures and low nutrient concentrations. North et al. (1986) indicated that summer nutrient depletion, together with high temperatures, is responsible for canopy die-off in Macrocystis. Additionally, light conditions have been demonstrated to be important for recruitment of Macrocystis pyrifera (Graham 1996). Similarly, survival of floating algae at the sea surface depends on several factors, including temperature (Hobday 2000a), damage caused by sunlight (Jokiel 1980), nutrient levels (Edgar 1987), excessive epibiont growth (Parr 1939), and destruction by animals (Thiel and Gutow 2005a). Thus, unfavorable conditions at the sea surface and low densities in kelp beds after the 1997-1998 El Niño may be the main reasons that no floating kelps were found in Arica and Iquique.

Floating kelp rafts were present in Mejillones $\left(23^{\circ} \mathrm{S}\right)$ and Caldera $\left(27^{\circ} \mathrm{S}\right)$, but these had no sporophylls (i.e. were not reproductive). Buschmann et al. (2004) showed that benthic populations of Macrocystis from the northern coast of Chile have their main reproductive activity during spring and winter but also had sporophylls during the rest of the year. Thus, reproductive seasonality cannot explain the complete absence of reproductive activity in floating kelp from these two northern sites. Reproduction in kelps is determined by environmental factors, such as light (irradiance, light quality, and photoperiod) and temperature (Lobban and Harrison 2000). Possibly, conditions at the sea surface in Mejillones and Caldera allowed a limited survival of floating kelp rafts but may have caused a rapid loss and absence of new production of sporophylls in floating algae due to light and nutrient stress. Reed (1987) found that experimental removal of $M$. pyrifera canopy biomass led to a significant decrease in sporophyll biomass. Observing that attached individuals completely stopped reproducing due to an episodic, sublethal, amphipod-grazing event that stripped blades from all sporophytes, Graham (2002) suggested a trade-off between sporophyte growth and reproduction in $M$. pyrifera. Amphipod grazers are common on floating kelp (Kingsford 1992) and might cause decreasing reproductive activity of floating rafts.

In contrast to what was found for the northern sites, floating kelp rafts from central Chile $\left(33^{\circ} \mathrm{S}\right.$ to $\left.42^{\circ} \mathrm{S}\right)$ contained a comparatively high percentage of sporophylls, possibly because environmental stress at the sea surface is less severe than in northern Chile. Nevertheless, in central and southern Chile, reproductive activity of floating kelps was lower than that of attached 


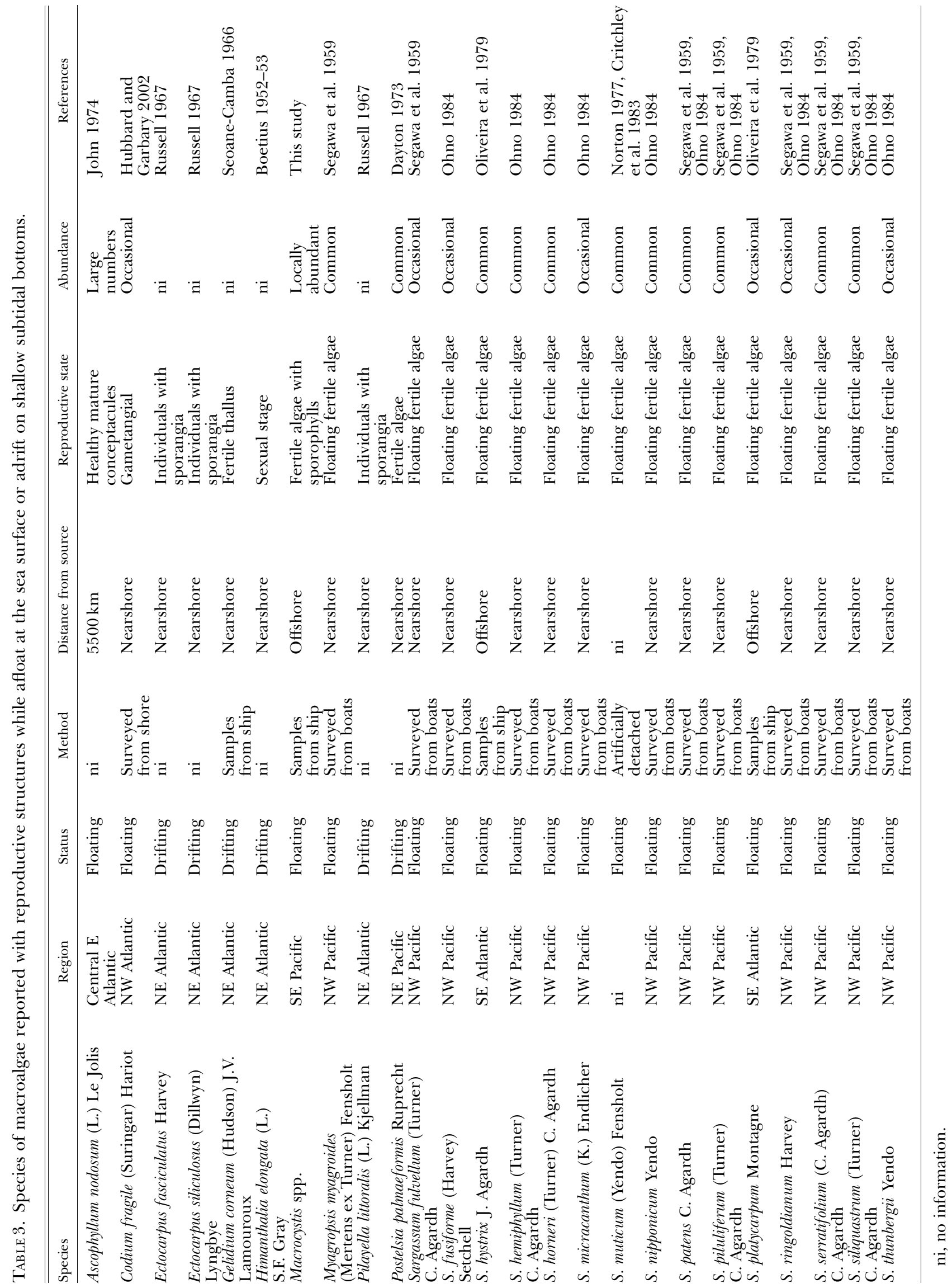


algae, indicating that conditions at the sea surface are not optimal for reproductive activity of sporophytes. An alternative explanation for the low presence of sporophylls in floating kelp rafts could be due to breakage of the stipe shortly above the holdfast, resulting in floating stipes with primarily vegetative blades and attached holdfasts with remnants of sporophylls. The fact that some of the kelp holdfasts from Concepción $\left(36^{\circ} \mathrm{S}\right)$ had suffered breakage supports this suggestion. On the other hand, we also found entire floating individuals (including holdfast) without any sporophylls, particularly in Mejillones and Caldera. In general, survival and continuing reproduction of floating kelp may only be possible in optimal conditions, that is, in the center of their geographic range.

Dispersal potential of Macrocystis spp. and other floating macroalgae. Dispersal processes depend on the characteristics of the macroalgae species as well as on the environment (Santelices 1990). The distance over which propagules are dispersed should be roughly dependent on the time spent in the water column (Shanks et al. 2003). In Macrocystis spp., dispersal via zoospores appears to occur over distances of only tens to hundreds of meters (Reed et al. 1988, Shanks et al. 2003). However, based on hydrodynamic modeling, Gaylord et al. (2002) suggested that dispersal of $M$. pyrifera may routinely extend over farther distances. We found several sporophytes of $M$. pyrifera with sporophylls floating at considerable distances off the Chilean coast. Many of these kelp rafts had been afloat for at least 2 weeks as indicated by the sizes of attached barnacles. The largest individuals of Lepas australis and $L$. pectinata we found to have a scutum length of $>8 \mathrm{~mm}$. Typical growth rates for these two species range between 0.22 and $0.32 \mathrm{~mm} \cdot \mathrm{d}^{-1}$ (Thiel and Gutow 2005b). Assuming similar growth rates for the stalked barnacles collected off the Chilean coast, it appears safe to assume that some of the samples found with sporophylls had been afloat for at least 21 days. During this time period and in the Humboldt Current system, these floating algae could have traveled distances of several $100 \mathrm{~km}$ (Thiel 2003).

Our study showed that sporophytes of Macrocystis spp. floating along the coast of Chile contained sporophylls, indicating continuous reproductive effort after detachment. Germination tests with floating kelps from Coquimbo $\left(30^{\circ} \mathrm{S}\right)$ confirmed that sporophylls from detached sporophytes indeed released a high proportion of viable zoospores during the summer months, that is, when all samples of floating kelp were taken. The germination of zoospores from floating sporophytes observed was similar to results from Candia et al. (1979) and Palacios and Mansilla (2003), who showed normal development of zoospores from benthic populations of $M$. pyrifera under laboratory conditions.

In general, the presence of reproductive structures on detached algae appears to be a common phenomenon in species from the families Lessoniaceae, Fuca- ceae, and Sargassaceae (Table 3). These considerations in combination with the results of our study support previous suggestions, namely that long-distance dispersal of macroalgae may occur via floating individuals or fertile algal fragments, which are transported by prevailing currents (Deysher and Norton 1982, van den Hoek 1987). High abundances of floating macroalgae have been observed in many regions of the worlds oceans (Thiel and Gutow 2005a), often at great distances from the nearest shores (van den Hoek 1987). Because dispersal distances of most algal spores or zygotes are limited (Fredriksen et al. 1995, Forrest et al. 2000, Dudgeon et al. 2001), transport of sporophylls or reproductive conceptacles in floating kelp rafts may be an important dispersal mechanism for some macroalgal species that float after detachment. In the case of species from the families Fucaceae and Sargassaceae, zygotes may be released from monoecious individuals, facilitating long-distance dispersal. However, our results also suggest that this mechanism may be restricted to particular conditions that are close to the optimal growth environment of these algae. Future studies should focus on the factors affecting survival and continuing reproductive activity in floating algae after detachment.

We are grateful to the crews of numerous research and fishing vessels for their cheerful assistance during this study. In particular, we thank the crew of Don Aquilino for their unconditional company while waiting several days for a chance to sample algae off the coast. We are very grateful to M. Graham and three anonymous reviewers for very constructive comments on the manuscript. Funding was provided through FONDECYT 1010356 to M. T., 1000044 to J. A. V., and 1010706 to A. H. B.

Anderson, E. K. \& North, W. J. 1966. In situ studies of spore production and dispersal in the giant kelp, Macrocystis. Proc. Int. Seaweed Symp. 5:73-86.

Bernstein, B. B. \& Jung, N. 1979. Selective pressures and coevolution in a kelp canopy community in southern California. Ecol. Monogr. 49:335-55.

Boetius, J. 1952-53. Some notes on the relation to the substratum of Lepas anatifera and Lepas fascicularis. Oikos 4:112-7.

Buschmann, A. H., Vasquez, J. A., Osorio, P., Reyes, E., Filun, L., Hernandez-Gonzalez, M. C. \& Vega, A. 2004. The effect of water movement, temperature and salinity on abundance and reproductive patterns of Macrocystis spp. (Phaeophyta) at different latitudes in Chile. Mar. Biol. 145:849-62.

Camus, P. A. 1994. Dinámica geográfica en poblaciones de Lessonia nigrescens Bory (Phaeophyta) en el norte de Chile: importancia de la extinción local durante eventos de El Niño de gran intensidad. Invest. Cient. y Tec. Ser. Cienc. Mar 3:58-70.

Candia, A., Romo, H., Alveal, K. \& Dellarossa, V. 1979. Cultivo unialgal de Macrocystis pyrifera (L) C. Agardh de la Bahía de Concepción - Chile. Rickia 8:75-83.

Chen, L. \& Lewin, R. A. 1976. Goose Barnacles (Cirripedia: Thoracica) on float beached at La Jolla, California. Fish B-NOAA 74:212-7.

Critchley, A. T., Farnham, W. F. \& Morrell, S. L. 1983. A chronology of the new European sites of attachment for the invasive brown alga, Sargassum muticum, 1973-1981. J. Mar. Biol. Assoc. UK 63:799-811.

Coyer, J. A., Smith, G. J. \& Andersen, R. A. 2001. Evolution of Macrocystis spp. (Phaeophyceae) as determined by ITS1 and ITS2 sequences. J. Phycol. 37:574-85. 
Dayton, P. K. 1973. Dispersion, dispersal, and persistence of the annual intertidal alga, Postelsia palmaeformis Ruprecht. Ecology $54: 433-8$.

Dayton, P. K. 1985. Ecology of kelp communities. Annu. Rev. Ecol. Syst. 16:215-45.

Dayton, P. K., Tegner, M. J., Parnell, P. E. \& Edwards, P. B. 1992. Temporal and spatial patterns of disturbance and recovery in a kelp forest. Ecol. Monogr. 62:421-45.

Deysher, L. \& Norton, T. A. 1982. Dispersal and colonization in Sargassum muticum (Yendo) Fensholt. J. Exp. Mar. Biol. Ecol. 56:179-95.

Deysher, L. E. \& Dean, T. A. 1986. Interactive effects of light and temperature on sporophyte production in the giant kelp Macrocycstis pyrifera. J. Exp. Mar. Biol. Ecol. 103:41-63.

Dudgeon, S., Kubler, J. E., Wright, W. A., Vadas, R. L. \& Petraitis, P. S. 2001. Natural variability in zygote dispersal of Ascophyllum nodosum at small spatial scales and its connection to recruitment. Funct. Ecol. 15:595-604.

Edgar, G. J. 1987. Dispersal of faunal and floral propagules associated with drifting Macrocystis pyrifera plants. Mar. Biol. 95:599-610.

Edwards, M. 2004. Estimating scale-dependency in disturbance impacts: El Niños and giant kelp forests in the northeast Pacific. Oecologia 138:436-47.

Forrest, B. M., Brown, S. N., Taylor, M. D., Hurd, C. L. \& Hay, C. H. 2000. The role of natural dispersal mechanisms in the spread of Undaria pinnatifida (Laminariales, Phaeophyceae). Phycologia 39:547-53.

Fredriksen, S., Sjøtun, K., Lein, T. L. \& Rueness, J. 1995. Spore dispersal in Laminaria hyperborea (Laminariales, Phaeophyceae). Sarsia 80:47-53.

Gaylord, B., Reed, D. C., Raimondi, P. T., Washburn, L. \& Mclean, S. R. 2002. A physically based model of macroalgal spore dispersal in the wave and current-dominated nearshore. Ecology 83:1239-51

Gaylord, B., Reed, D. C., Washburn, L. \& Raimondi, P. T. 2004. Physical-biological coupling in spore dispersal of kelp forest macroalgae. J. Mar. Syst. 49:19-39.

Graham, M. H. 1996. Effect of high irradiance on recruitment of the giant kelp, Macrocystis (Phaeophyta), to shallow water. J. Phycol. 32:903-6.

Graham, M. H. 2002. Prolonged reproductive consequences of short-term biomass loss in seaweeds. Mar. Biol. 140: 901-11.

Helmuth, B. S., Veit, R. R. \& Holberton, R. 1994. Long-distance dispersal of a subantarctic brooding bivalve (Gaimardia trapesina) by kelp rafting. Mar. Biol. 120:421-6.

Hobday, A. J. 2000a. Abundance and dispersal of drifting kelp Macrocystis pyrifera rafts in the Southern California Bight. Mar Ecol. Prog. Ser. 195:101-16.

Hobday, A. J. 2000b. Age of drifting Macrocystis pyrifera (L.) C. Agardh rafts in the Southern California Bight. J. Exp. Mar. Biol. Ecol. 253:97-114.

Hoffman, A. J. 1987. The arrival of seaweed propagules at the shore: a review. Bot. Mar. 30:151-65.

Hooker, J. D. 1847. Algae. In The Botany of the Antartic Voyage of $H$. M. Discovery Ships Erebus and Terror in the Years 1839-1843. I. Flora Antarctica, Part 2. Reeve, London, pp. 454-502.

Hubbard, C. B. \& Garbary, D. J. 2002. Morphological Variation of Codium fragile (Chlorophyta) in Eastern Canada. Bot. Mar. 45:476-85.

Ingólfsson, A. 1998. Dynamics of macrofaunal communities of floating seaweed clumps off western Iceland: a study of patches on the surface of the sea.J. Exp. Mar. Biol. Ecol. 231:119-37.

John, D. M. 1974. New records of Ascophyllum nodosum (L.) Le Jol. from the warmer parts of the Atlantic Ocean. J. Phycol. 10: 243-44.

Jokiel, P. K. 1980. Solar ultraviolet radiation and coral reef epifauna. Science 207:1069-71.

Kingsford, M. J. 1992. Drift algae and small fish in coastal waters of northeastern New Zealand. Mar. Ecol. Prog. Ser. 80:41-55.

Ladah, L., Zertuche-Gonzalez, J. \& Hernandez-Carmona, G. 1999. Giant kelp (Macrocystis pyrifera, Phaeophyceae) recruitment near its southern limit in Baja California after mass disappearance during ENSO 1997-1998. J. Phycol. 35:1106-12.

Lobban, C. S. \& Harrison, P. J. 2000. Seaweed Ecology and Physiology. Cambridge University Press, Cambridge, 366 pp.

Mansilla, A., Palacios, M., Navarro, N. \& Riquelme, V. 2003. Variación estacional de biomasa húmeda y estado reproductivo de Macrocystis pyrifera $(L)$ C. Agardh en Bahía Porvenir, Tierra del Fuego. Libro de resúmenes XXIII Congreso de Ciencias del Mar, Punta Arenas, Chile, 77 pp.

Martinez, E. A., Cardenas, L. \& Pinto, R. 2003. Recovery and genetic diversity of the intertidal kelp Lessonia nigrescens 20 years after El Niño 1982/83. J. Phycol. 39:504-8.

North, W. J. 1994. Review of Macrocystis biology. In Akatsuka I. [Ed.] Biology of Economic Algae. SPB, Academic Publishing, The Hague, pp. 447-527.

North, W. J., Jackson, G. A. \& Manley, S. L. 1986. Macrocystis and its environment, knowns and unknowns. Aquat. Bot. 26:9-26.

Norton, T. A. 1977. Ecological experiments with Sargassum muticum. J. Mar. Biol. Assoc. UK 57:33-43.

Norton, T. A. \& Mathieson, A. C. 1983. The biology of unattached seaweeds. In Round, F. E. \& Chapman, D. J. [Eds.] Progress in Phycological Research. Vol. 2. Elsevier, New York, pp. 333-86.

Ohno, M. 1984. Algological observation on the floating seaweeds of offshore water of Shikoku Island in Japan. B. Jpn. Soc. Sci. Fish. 50:1653-6. [In Japanese with English summary.]

Oliveira, E. C., Ugadim, Y. \& de Paula, E. J. 1979. Associated epibiota on Sargassum floating on the waters of the Brazilian Current-biogeographical remarks. Bol. Bot. Univ. S. Paulo 7:5-9.

Palacios, M. \& Mansilla, A. 2003. Desarrollo de gametofitos y esporofitos de Macrocystis pyrifera (L) C. Agardh (Laminariales: Lessoniaceae) de la Región de Magallanes en condiciones de laboratorio. Anal. Inst. Patagonia 31:43-53.

Parr, A. E. 1939. Quantitative observations on the pelagic Sargassum vegetation of the western North Atlantic. B. Bingham Oceanogr. C. 6:1-94.

Peters, A. F. \& Breeman, A. M. 1993. Temperature tolerance and latitudinal range of brown algae from temperate Pacific South America. Mar. Biol. 115:143-50.

Reed, D. C. 1987. Factors affecting the production of sporophylls in the giant kelp Macrocystis pyrifera. J. Exp. Mar. Biol. Ecol. 113:61-9.

Reed, D. C., Laur, D. R. \& Ebeling, A. W. 1988. Variation in algal dispersal and recruitment: the importance of episodic events. Ecol. Monogr. 58:321-35.

Reed, D. C., Neushul, M. \& Ebeling, A. W. 1991. Role of density in gametophyte growth and reproduction in the kelps Macrocystis pyrifera and Pterygophora californica. J. Phycol. 27:361-6.

Reed, D. C., Schroeter, C. S. \& Raimondi, P. T. 2004. Spore supply and habitat availability as sources of recruitment limitation in the giant kelp Macrocystis pyrifera (Phaeophyceae). J. Phycol. 40:275-84.

Russell, G. 1967. The ecology of some free-living Ectocarpaceae. Helgol. Wiss. Meeresunters. 15:155-62.

Santelices, B. 1990. Patterns of reproduction, dispersal and recruitment in seaweeds. Oceanogr. Mar. Biol. Annu. Rev. 28: $177-276$.

Segawa, S., Sawada, T., Higaki, M. \& Yoshida, T. 1959. Studies on floating algae. III. Some considerations on the formation of floating algae. Sci. Bull. Fac. Agric. Kyushu Univ. 17:299-305. [In Japanese with English summary.].

Seoane-Camba, J. A. 1966. Algunos datos de interés en la recolección de Gelidium sesquipedale (Clemente) Thuret. Publicaciones Técnicas de la Junta de Estudios de Pesca. Madrid 5:437-55.

Shanks, A. L., Grantham, B. \& Carr, M. 2003. Propagule dispersal distance and the size and spacing of marine reserves. Ecol. Appl. 13:159-69.

Smith, S. D. A. 2002. Kelp rafts in the Southern Ocean. Global Ecol. Biogeogr. 11:67-9.

Stegenga, H. \& Mol, I. 1983. Flora van de Nederlandse Zeewieren. Koninkl. Ned. Natuurhist. Ver. Hoodwoud, Netherlands, 263 pp.

Tegner, M. \& Dayton, P. 1991. Sea urchins, El Niño, and long term stability of Southern California kelp forest communities. Mar. Ecol. Prog. Ser. 77:49-63. 
Thiel, M. 2003. Rafting of benthic macrofauna: important factors determining the temporal succession of the assemblage on detached macroalgae. Hydrobiologia 503:49-57.

Thiel, M. \& Gutow, L. 2005a. The ecology of rafting in the marine environment. I. The floating substrata. Oceanogr. Mar. Biol. Anпи. Rev. 42:181-264.

Thiel, M. \& Gutow, L. 2005b. The ecology of rafting in the marine environment. II. The rafting organisms and community. Oceanogr. Mar. Biol. Annu. Rev. 43:281-420.

Thiel, M., Hinojosa, I., Vásquez, N. \& Macaya, E. 2003. Floating marine debris in coastal waters of the SE-Pacific (Chile). Mar. Pollut. Bull. 46:224-31. van den Hoek, C. 1987. The possible significance of long-range dispersal for the biogeography of seaweeds. Helgol. Meeresunters. 41:261-72.

Vásquez, J. A. \& Buschmann, A. H. 1997. Herbivory-kelp interactions in subtidal chilean communities: a review. Rev. Chil. Hist. Nat. 70:41-52.

Vega, J. M. A., Vasquez, J. A. \& Buschmann, A. H. 2005. Population biology of the subtidal kelps Macrocystis integrifolia and Lessonia trabeculata (Laminariales: Phaeophyta) in an upwelling ecosystem of northern Chile: interannual variability and El Niño 1997-98. Rev. Chil. Hist. Nat 78: $33-50$. 